\title{
Pathological changes in African hyperoliid frogs due to a myxosporidian infection with a new species of Hoferellus (Myxozoa)
}

\author{
F. Mutschmann* \\ Exomed - Institute for Veterinary Medicine in Lower Vertebrates and Exotic Pets, Am Tierpark 64, 10319 Berlin, Germany
}

\begin{abstract}
A proliferous, polycystic and sometimes fatal kidney disease due to an infection with myxosporidia is reported in 24 of 28 hyperoliid frogs (Afrixalus dorsalis, Hyperolius concolor, Hyperolius sp.) from Nigeria, Ghana and Tanzania. In line with pathological changes in fish, the disease is described as 'frog kidney enlargement disease' (FKED). Myxosporidian plasmodia, different developmental stages and spores occurred in the kidney, ureter, and urinary bladder and in the intestine of the frogs. The parasite belongs to the genus Hoferellus and is presented as a new species: H. anurae n. sp. Spores are similar in size and structure to other Hoferellus species in fish but differ by the presence of a more prominent suture line and shorter caudal appendages. This is the first report on a Hoferellus species in amphibians as well as the first report of the genus Hoferellus in African vertebrates.
\end{abstract}

KEY WORDS: Myxozoa · Myxosporidia · Hoferellus anurae sp. n. · Amphibia · Frog · Frog kidney enlargement disease $\cdot$ FKED

Resale or republication not permitted without written consent of the publisher

\section{INTRODUCTION}

In 1898 Hoferellus cyprini was described by Doflein (1898) from the kidney of the common carp Cyprinus carpio L. In the renal tubules he found stages 20 to $30 \mu \mathrm{m}$ in diameter and pyramidal, longitudinal striated spores with 2 polar capsules and characteristic, brush-like caudal projections. Another species of the genus Hoferellus was identified by Achmerov (1960) in the gibel carp Carassius auratus gibelio and named $H$. carassii. In the same year Golikova (1960) described $H$. schulmanni from the crucian carp Carassius carassius. The spores of these 2 species resembled $H$. cyprini but differed by having bristlelike filaments at the caudal ends.

Fujita (1912) reported a Hoferellus cyprini-like parasite in the renal tubeles of the common carp and the goldfish Carassius a. auratus in Japan and named it Mitraspora cyprini. This species also differs from $H$. cyprini by having bristle-like filaments at the ends of the spores. Further studies on $M$. cyprini showed a $1 \mathrm{yr}$ developmental cycle with intracellular stages in the epithelium of renal tubules in summer and autumn; plasmodia occurred in the tubular lumina in winter and spores in the spring. Infected fish show a polycystic formation and swelling of the kidneys. This resulted in a pathology named 'kidney enlargement disease' (KED) (Ahmed 1973, 1974). The first record of $M$. cyprini in Europe (in former Czechoslovakia) was reported in 1981 by Lom \& Dyková. Further records of $M$. cyprini in the common carp in Germany were reported by Körting \& Hermanns $(1984,1985)$. No reports could be found on Hoferellus or Mitraspora outside Europe or Asia. Lom \& Noble (1984) pointed out that the genus Hoferellus needed a revision and placed it in the Family Myxobolidae (Suborder Platysporina). Molnár et al. (1986) demonstrated that $M$. cyprini was identical with H. cyprini. Nowadays the genus Mitraspora (Fujita, 1912) is considered to be a synonym of the genus Hoferellus Berg, 1898 (Molnár et al. 1986, Lom 1990). 
The genus Hoferellus is now classified in the family Sphaerosporidae (Lom 1990). Members of this family are characterised by having 2 polar capsules, perpendicular to the sutural line and opening at the anterior pole of the spores. The spores are spherical, rounded triangular, or elongated and some species have caudal appendages.

The life cycle of Hoferellus cyprini was originally studied by Plehn (1924). She found a 1 yr developmental cycle with production of mature spores at the end of the winter. In addition to plasmodial formations and spores in the lumen of the renal tubules, she considered intracellular foci in the epithelial cells of the tubules to be early developmental stages. Trouillier et al. (1996) found the actinosporean stage of $H$. carassii in an oligochaete intermediate host (genus Nais) and describes it as an Aurantiactinomyxon. Furthermore, these authors noted a plasmodial development of $H$. carassii within the urinary bladder of the goldfish.

In amphibians, renal myxosporidiosis is a frequent parasitosis caused by the genera Sphaerospora (Wardia), Leptotheca and Chloromyxum (e.g. Ohlmacher 1893, Thélohan 1895, Joseph 1905, Kudo 1926, Levine \& Nye 1977, Desser et al. 1986, Mutschmann 1999). However, the genera and species causing myxosporidiosis in amphibians have been less elaborated than those parasitising fish. To the best of my knowledge Hoferellus has not been described in amphibians.

\section{MATERIALS AND METHODS}

In October 1999, spring 2000 and January 2001, 18 hyperoliid frogs of the species Afrixalus dorsalis Peters, 1875 from Nigeria as well as 5 specimen of Hyperolius concolor ( 3 adults, 2 juveniles) were dissected in our laboratory. These frogs had been imported for the pet trade and died 1 to $8 \mathrm{~d}$ after arrival. Additionally, in December 1999, 5 adult hyperoliid frogs (3 males, 2 females) were also dissected for routine diagnosis. The frogs were freshly imported from Tanzania for scientific reasons; they died during air transport and were identified by the importer as Hyperolius marmoratus Rapp, 1842. In contrast to this identification, this species is more widely distributed in coastal regions of southern Africa and seems not to be an indigenous Tanzanian species. H. marmoratus is markedly variable in colour and pattern, like other members of the family Hyperoliidae. The taxonomical status is unclear and needs further work (Schiøtz 1999). Without better knowledge of the origin and habitats of these frogs, they are treated here as Hyperolius spp.

Histological slides were prepared from the skin and all inner organs using standard techniques and stained with haematoxylin-eosin (H\&E), Ziehl-Neelsen (Z\&N) and May-Gruenwald (M\&G). Contents of the stomach, gut, gall and urinary bladders were studied in wet mounts by light microscopy and stained routinely with silver nitrate, Giemsa stain and trichrome stain to look for protozoans. The chyme from the gut was also subjected to parasitological investigation using the merthiolate-iodine-concentration method (MIFC). Portions of kidneys were cut into thin slices and squashed on agar-covered microscope slides (Lom \& Dyková 1992) for myxozoan observation. In some preparations a drop of Lugol's solution was added to detect iodophile vacuoles. Kidney impression smears and smears of blood stained with Giemsa were also made, as well as preparations labelled with a non-specific fluorescent brightener (Calcofluor white M2R fluorescent brightener 28, Sigma-Aldrich).

For light and fluorescent microscopy, microphotographs and measurements, a 'Jenamed 2' (Zeiss) was used.

\section{RESULTS}

\section{Pathological findings}

In 16 of 18 Afrixalus dorsalis (5 males, 11 females) and 3 Hyperolius concolor of 5 ( 3 males) specimens examined the kidneys appeared swollen and had a bright yellow or orange appearance. The renal surface appeared rough or granulated compared to the other frogs without swollen kidneys. In these 19 frogs a myxosporidian infection of the kidneys was detected by light microscopy of fresh impression smears. Spore-like parasitic stages were located in the Bowman's capsules and renal tubular epithelia. The lumen of the renal tubules contained mature plasmodia and free spores of the parasite. Sometimes the lumen was totally replete with the parasites. Infected epithelial cells of tubules containing sporoplasm and/or spores appeared enlarged. The nuclei of these cells were pyknotic, they were displaced toward the basement membrane. Occasionally, the epithelial cells had been destroyed and were necrotic. In 13 of 19 infected frogs a local, nodular degeneration of the glomeruli and tubules was found associated with histiocytes and granulocytes as well as myxosporidian stages. In the remaining infected frogs no inflammatory reaction could be found associated with the parasite. Infected frogs showed a high concentration of uric acid and/or hyaline-like substances in and around the areas infected by the parasites. In 2 juvenile $H$. concolor (1 male, 1 female) with a low number of myxosporidia, no pathological changes were detected associated with myxosporidian infection.

In 4 frogs, myxosporidia identical to stages in the kidney (spores and plasmodia) were also found in the 
lumen of the small intestine. No developmental stages were seen inside the epithelial cells of the gut.

In 3 of 5 specimens of Hyperolius sp. (1 male, 2 females) the kidneys appeared swollen with an orange or bright red colour and contained macroscopically visible rounded, cyst-like protrusions on the surface (with diameters up to $1.8 \mathrm{~mm}$ ). The cysts were filled with liquid and had a pale yellow or greenishblue colour. The liquid contained many plasmodia, free spores and sporoblastic stages of a myxozoon as well as blood cells, bacteria and, in one case, developmental stages of a fungus that was identified as a Geotrichium species. On histological examination the kidneys displayed a multifocal granulocytic and lymphocytic infiltration and oedema. The cyst walls were formed by the capsule of the kidney due to the destruction of Bowman's capsules and the renal tubules. In circumscribed areas, the epithelium of the renal tubules showed either hypertrophy or necrosis. These areas contained a large number of myxosporidia in different developmental stages (spores, 1or multi-nucleated cells and pansporoblasts) and also focal accumulations of granulocytes. In the areas surrounding theseregions, the parasites were also found in the interstice and inside the Bowman's capsules. Around the highly infected areas, solitary cells of tubular epithelium containing parasitic stages alternated with regions free of parasites. Epithelial cells infected with myxosporidia were enlarged, and in most cases the nuclei were displaced towards the basal membrane as in the Afrixalus dorsalis specimens. In some areas the contents of the epithelial cells had been totally destroyed and the tubules had collapsed. Degenerated tubules also showed the presence of hyaline droplets both in the epithelia and lumina. Such hyaline droplets were not found in the 2 uninfected Hyperolius sp. frogs. In several renal tubules the lumen was filled with trophozoites and free spores of the parasite.

In the ureters and urinary bladders, plasmodia and free spores were also found. Vegetative stages (plasmodia) were either present free in the urine or adhering to the wall of the bladder. Parasitic stages (sporoplasm, pansporoblasts) were found in the epithelium of the ureter but not inside epithelial cells of the urinary bladder in 1 male frog, which was heavily infected.

The intestinal chyme contained plasmodia and mature spores. Histological sections of the small intestine showed a high load of parasitic stages inside the epithelial cells of the intestinal villi as well as free stages (plasmodia and mature spores) in the lumen. Large plasmodia from the intestinal lumen were seen as irregularly shaped transparent bodies, which were divided into rounded chambers, thus producing a 'foam-like' structure with big bubbles. Intestinal epithelial cells were hypertrophic and later tended to become necrotic in some areas of the intestinal surface. There were no signs of an inflammatory reaction in the gut. Parasitic stages were not found in the liver, stomach or gall bladder nor in the heart, lungs, bones, skeletal muscles, gonads, central nervous system or skin.

Intracellular developmental stages (early plasmodia) in epithelial layers of gut, kidney and ureter were spherical, 5 to $9 \mu \mathrm{m}$ in diameter and contained 4 to 14 daughter cells. In some fresh impressions and histological sections (H\&E and M\&G staining) of the kidneys these plasmodia appeared as vacuoles. Later vegetative stages could be seen in the lumina of the Bowman's capsules, renal tubules, gut, ureters and urinary bladder or adhering to the epithelial wall of the gut. Some of these stages in the gut appeared as transparent bodies containing large spherical vacuoles as described above. Spores and plasmodia were in the same size and structure as the myxosporidians found in Afrixalus dorsalis.

In Calcofluor-labelled preparations, the mature spores (with well-developed chitiniced spore walls) from both frog species showed a bright and fluorescent surface. Immature spores were negative in fluorescence. A detailed description of the myxosporidian is given below.

\section{Other findings}

In all the frogs investigated, the intestine contained different types of non-identified nematodes (larvae and adults). The posterior part of the intestines contained some zooflagellates and masses of opalinids (Opalina sp., Protoopalina sp.). In the Hyperolius spp. the skin and lungs were also infested with different nematodes. Nine out of 18 Afrixalus dorsalis harboured adult Nematotaenia-like cestodes (Cyclophyllidae: Nematotaeniidae) in the intestine. In $3 \mathrm{~A}$. dorsalis and all specimen of Hyperolius spp. unidentified metacercariae of trematodes were found in the intestinal wall, skin and skeletal muscles. All Hyperolius specimens displayed a low-grade infection with trypanosomes in the peripheral blood and kidney impression preparations. The morphology of the trypanosomes was similar to that of Trypanosoma chattoni Mathis and Leger, 1911 (Bardsley \& Harmsen 1973).

\section{Species description}

Myxosporea Bütschli, 1881

Bivalvulida Schulman, 1959

Variisporina Lom, 1984

Sphaerosporidae Davis, 1917

Hoferellus anurae sp. n. (Fig. 1) 


\section{Hosts and locality:}

Holotype:

Afrixalus dorsalis Peters, 1875 from Nigeria.

Paratypes:

Hyperolius concolor Hallowell, 1844 from Ghana.

Hyperolius sp. from Tanzania (Anura: Hyperoliidae)

(No exact information about the origin of the frogs could be obtained).

Site of infection: Kidney, intestine, urinary bladder and in Hyperolius spp. also in the ureter.

\section{Prevalence:}

16/18 (88.8\%) in Afrixalus dorsalis.

$5 / 5(100 \%)$ in Hyperolius concolor.

$3 / 5(60 \%)$ in Hyperolius sp.

Spore: Laterally flat, pyramidal or 'mitra-like with a slightly elongated, rounded, anterior apex. The posterior end is either flat or has a saucer-shaped depression with 2 small outgrowths from the lateral edges and sometimes 1 extra outgrowth from the suture line. Spore size ( $\mathrm{n}=50)$ : length: $8.0 \mu \mathrm{m}$ (7.0 to 8.9), maximal width (sutural view): $7.9 \mu \mathrm{m}$ (6.1 to 7.9 ), thickness: $4.9 \mu \mathrm{m}$ (4.5 to 5.2 ). The suture line is prominent and 0.8 to $1.1 \mu \mathrm{m}$ wide. The shell wall is 0.7 to $0.1 \mu \mathrm{m}$ in thickness. The surface of the spore has 8 to 10 longitudinal striations or ridges, starting at the anterior apex and occasionally extending to the short, brush-like, caudal filaments (length: 1.2 to $3.2 \mu \mathrm{m}$ ). Two pyriform polar capsules are located at the anterior end, in a plane parallel to the suture line of the shell valves, size ( $\mathrm{n}=$ 20): $3.8 \mu \mathrm{m}(3.2$ to 4.3$) \times 2.0 \mu \mathrm{m}(1.8$ to 2.1$)$. The polar filament is thin $(0.6$ to $0.8 \mu \mathrm{m})$, coiled in 6 to 7 turns inside the polar capsules. The length of the extruded filaments is 45 to $52 \mu \mathrm{m}(\mathrm{n}=20)$. The amoeboid germ contains an iodophile vacuole and 2 rounded nuclei.

Plasmodia: Spherical or arranged as an irregular assemblage of large plasmodia, which are surrounded by a thin ectoplasmatic layer (in the gut and urinary bladder). In the kidney the plasmodia are ovoid to elliptical with amoeboid ectoplasmatic protrusions. Early stages present in the epithelial cells of the renal tubules, ureters and the gut, containing 4 to 14 daughter cells, which are 6 to $13 \mu \mathrm{m}$ in diameter and display no visible ectoplasm. Later stages in the lumina of gut, renal tubules, ureter and urinary bladder appear transparent with spherical droplets. These stages contain a granular endoplasm with refractile droplets and pansporoplasts as well as free mature spores. Ectoplasm and endoplasm are not well differentiated. Maximal size measured in impression smears (lumen of intestine): $123 \times 196 \mu \mathrm{m}$ in diameter. Pansporoblast: polysporoblastic (1 to 6 spores).

Types are deposited as photographs, Giemsastained preparations and histological sections in the protozoological collection of the Zoological Museum of Berlin (ZMB Prot. 1) (Figs. 2 to 13).

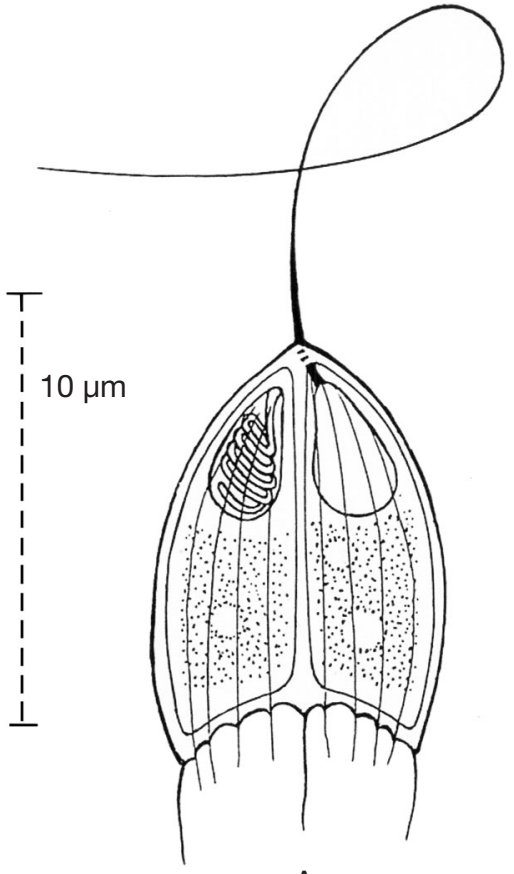

A

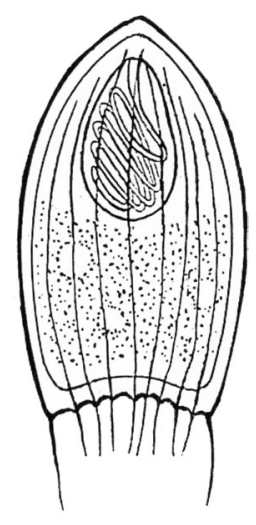

B
Fig. 1. Hoferellus anurae. Line drawing of a mature spore.(A) dorsal view; (B) lateral view

\section{DISCUSSION}

The pathological changes in the kidney described above are specific for the presence of Hoferellus and can be differentiated from the pathologies caused by nematodes, metacercariae, bacteria or fungi, which sometimes may also be present in the same frog. The myxosporidian parasite described herein is not strictly host specific. It seems to be distributed over a wide area in hyperoliid frogs, ranging from western subsaharan parts of Africa to eastern territories such as Tanzania. The parasite has not been recognised in ranid or bufonid anurans from the same areas, which have also been examined over the last $10 \mathrm{yr}$.

Neither renal enlargement nor polycystic degeneration was found in hyperoliid frogs free of renal myxosporidiosis. The destructive influence of the parasite on renal tissue is similar to that reported from cyprinid fish by Plehn (1924), Ahmed (1973, 1974) and Molnár et al. (1986). On the basis of Ahmed's (1973) description of a similar disease in fish, I propose the name 'frog kidney enlargement disease (FKED)' for the infection in frogs.

The renal cysts resulted from the combined activity of the inflammatory processes, oedema and tissue destruction, and were not directly caused by the parasites themselves. In Hyperolius spp. the cysts were more prominent and larger, and the inflammatory reactions were more extensive than in Afrixalus dor- 


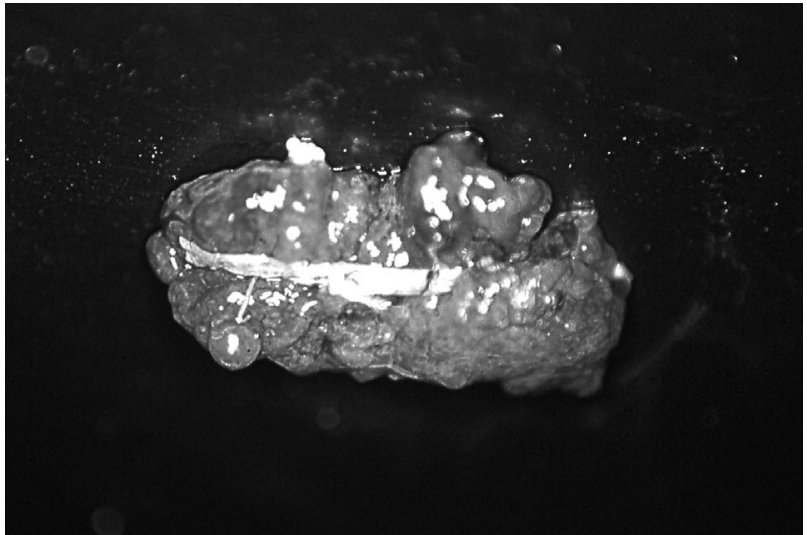

Fig. 2. Hyperolius sp. Kidney with macroscopically visible cysts $(\times 3)$

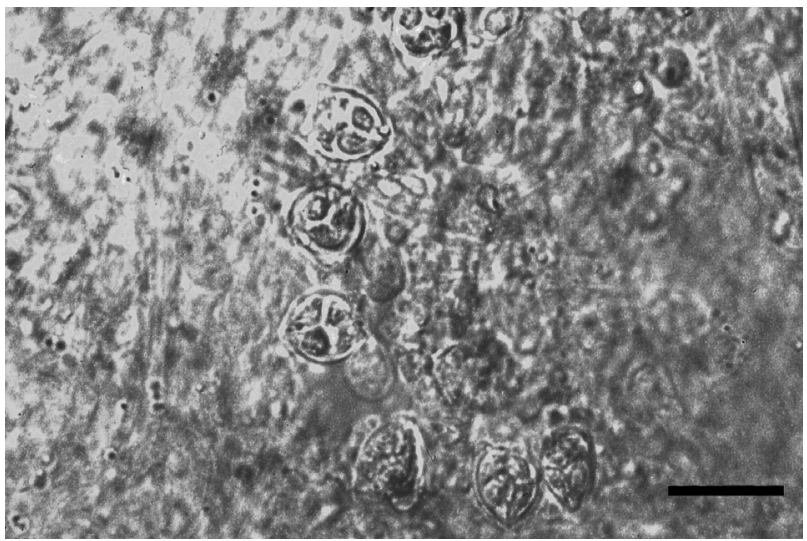

Fig. 4. Hoferellus anurae. Mature and immature spores from the small intestine of Afrixalus dorsalis. Scale bar $=10 \mu \mathrm{m}$

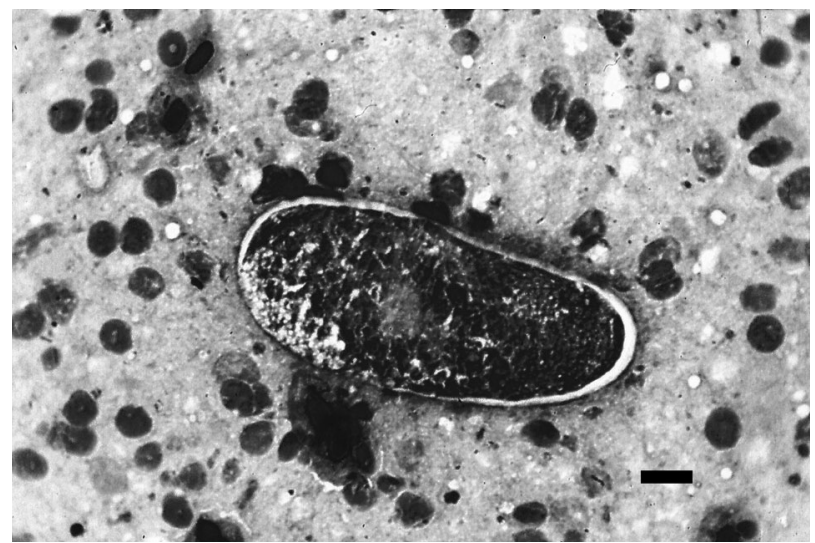

Fig. 6. Hyperolius sp. Plasmodium from the kidney (Giemsa). Scale bar $=10 \mu \mathrm{m}$

salis and Hyperolius concolor. These features may have been due to the poor condition of the Hyperolius sp. specimens, caused by either helminths and other pathogens, or a higher pathogenicity of the parasite in this species (alien host?). Further investigations are needed to clarify this point.

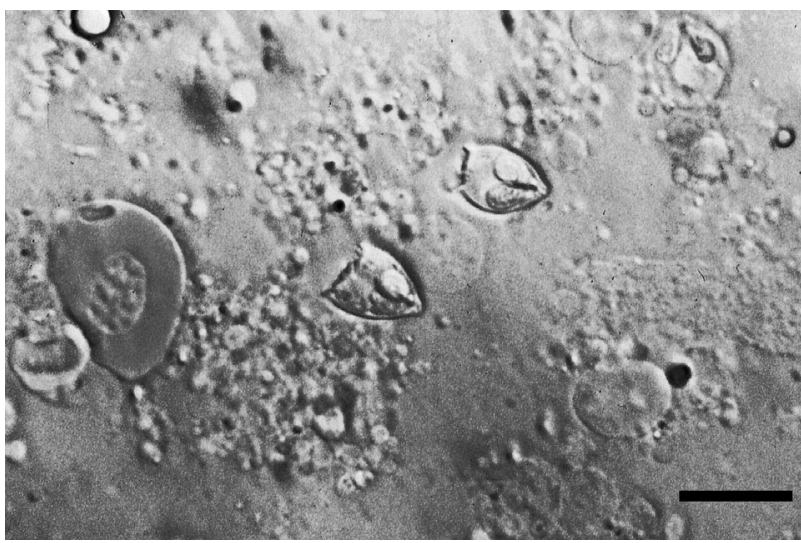

Fig. 3. Hoferellus anurae. Fresh unfixed spores (Hyperolius dorsalis, kidney imprint). Scale bar $=10 \mu \mathrm{m}$

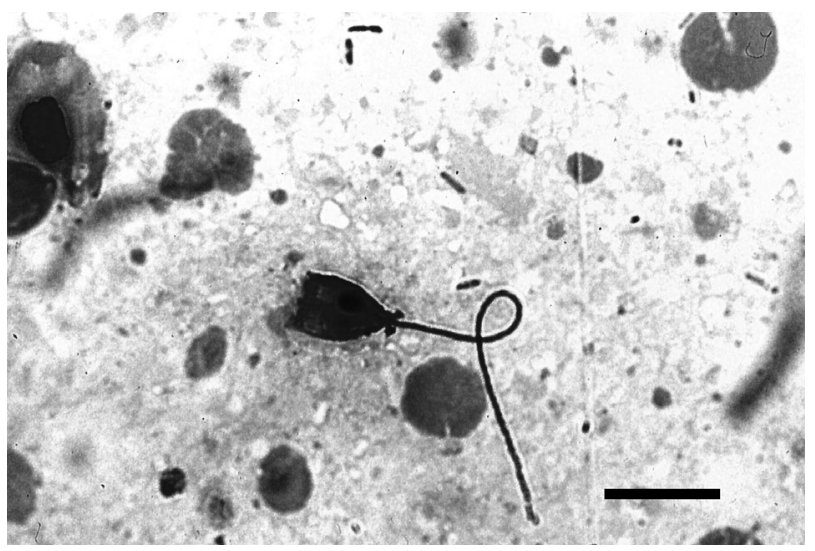

Fig. 5. Hoferellus anurae. Mature spore with protrusion of a polar filament from Hyperolius concolor (Giemsa). Scale bar $=10 \mu \mathrm{m}$

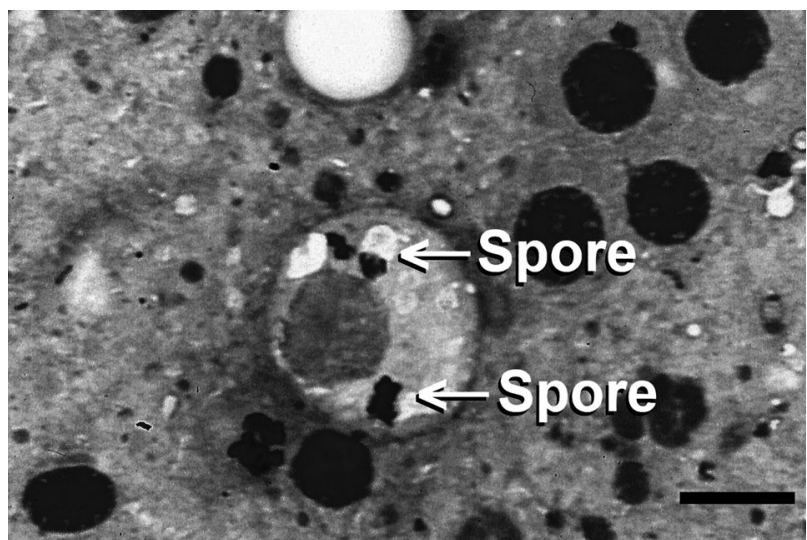

Fig. 7. Afrixalus dorsalis. Giemsa-stained plasmodium formation with immature spores from the kidney. Scale bar $=10 \mu \mathrm{m}$

Hyaline-like deposits in renal tubular epithelium and lumina may be associated with cell necrosis. These deposits seem to be a result of reabsorption of an excessive amount of proteinacaeous material from the primary urine (Desser et al. 1986). The fact that such deposits were not detected in the uninfected speci- 


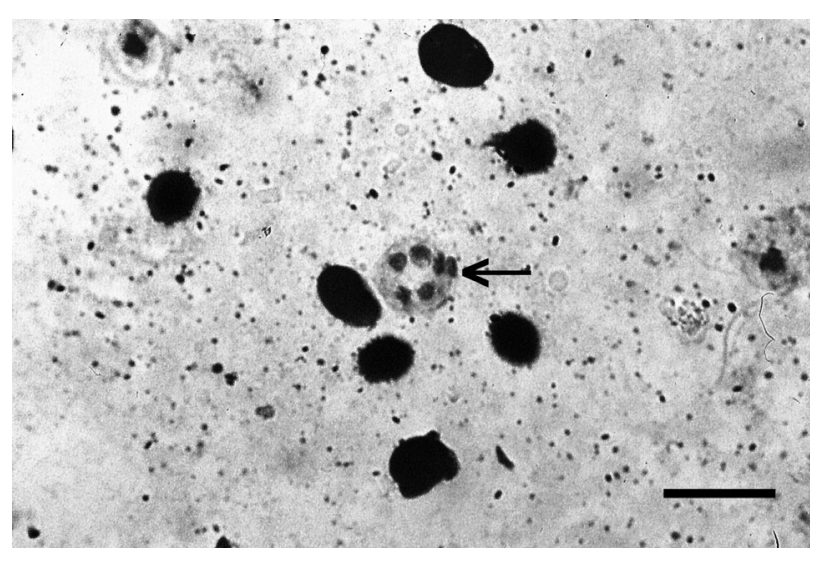

Fig. 8. Hyperolius sp. Early plasmodium (kidney, Giemsa). Scale bar $=10 \mu \mathrm{m}$

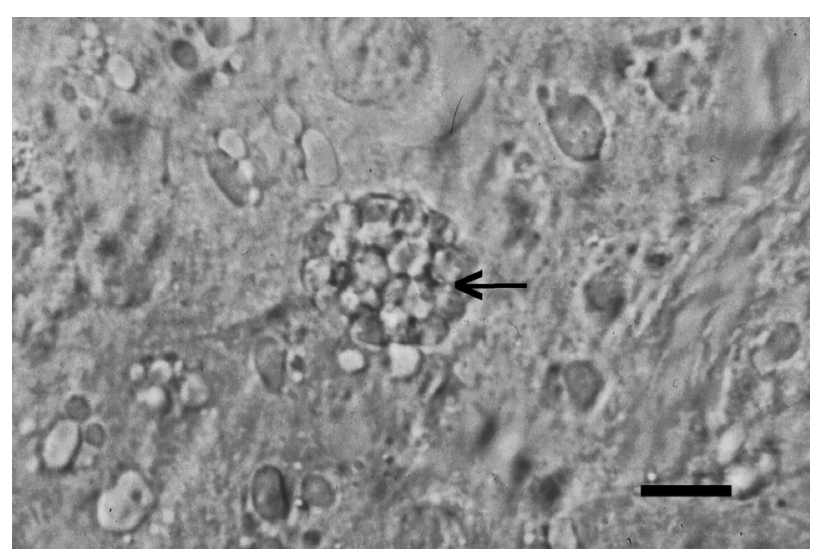

Fig. 10. Hyperolius sp. Plasmodium from the small intestine (unstained). Scale bar $=10 \mu \mathrm{m}$

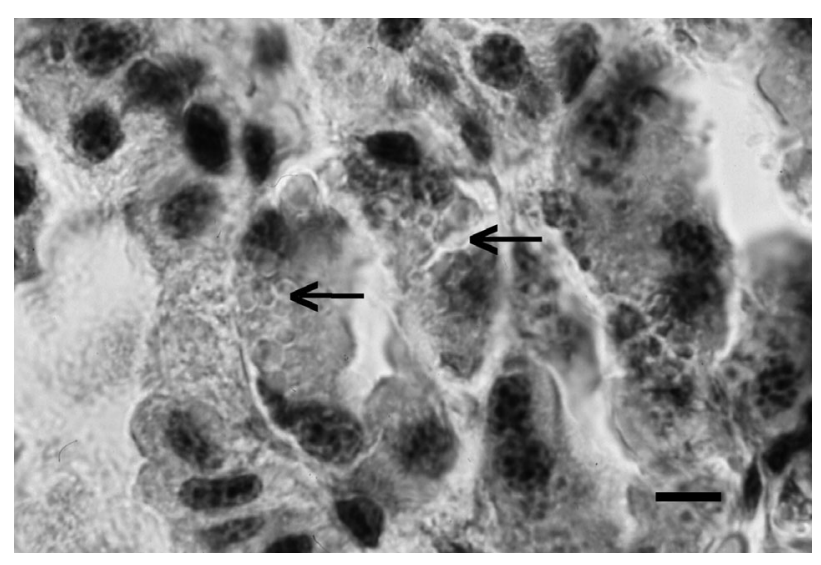

Fig. 12. Afrixalus dorsalis. Hoferellus-infected area of renal tubules $(\mathrm{M} \& \mathrm{G})$. Scale bar $=10 \mu \mathrm{m}$

mens suggests that the accumulation resulted from the lesions caused by the parasites.

The presence of developmental stages and spores of the parasite inside the epithelium and lumen of the

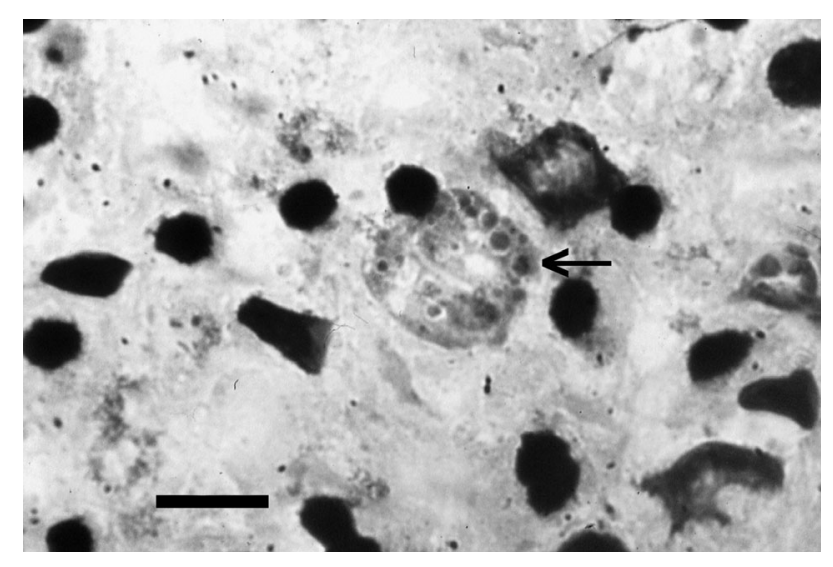

Fig. 9. Hyperolius concolor. Sporoblast from the kidney (Giemsa). Scale bar $=10 \mu \mathrm{m}$

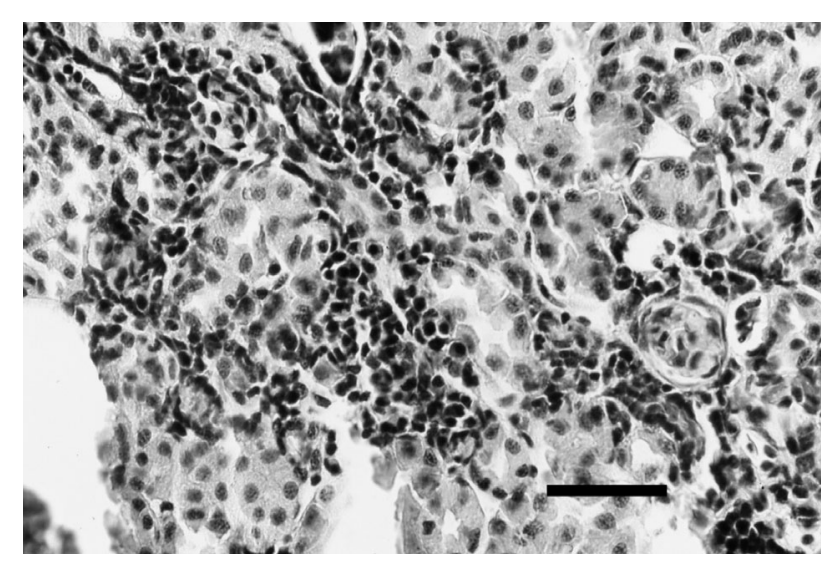

Fig. 11. Hyperolius sp. Cross-section of infected kidney with masses of inflammatory cells, degenerated tubules and tissue destruction (H\&E). Scale bar $=100 \mu \mathrm{m}$

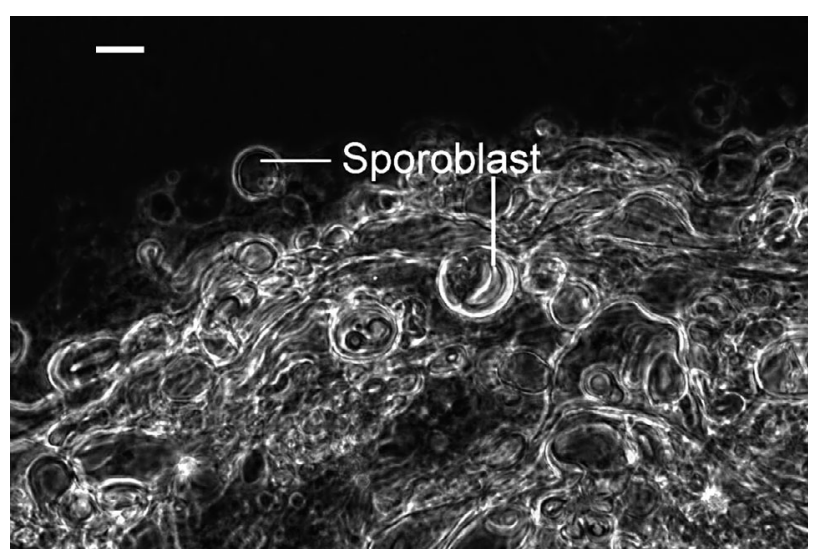

Fig. 13. Hyperolius spp. Wet mount preparation of a plasmodial formation adhering the epithelium of renal tubules containing pansporoblasts of Hoferellus anurae. Scale bar $=10 \mu \mathrm{m}$

intestine has not been reported previously in Hoferellus spp. In contrast to the report by Trouillier et al. (1996) concerning goldfish, there were no signs of parasite development within the epithelium of the urinary 
bladder of the frogs. The occurrence of the parasite in solitary epithelial cells of renal tubules and in the interstice of the kidneys corresponded with the situation reported by Molnár et al. (1986) for common carp infected with $H$. cyprini.

The pathological changes are characteristic of a progressive disease. This myxosporeotic parasitosis can cause destructive processes in the kidney which can lead to the loss of renal function and reduced vitality of the affected frogs, as well as to metabolic imbalances, often with fatal consequences. The situation is identical to renal myxosporidiosis in Asian horned frogs Megophrys nasuta from Indonesia infected with Chloromyxum careni (Mutschmann 1999, Duncan 2000). However, in contrast to the C. careni infection, no renal cysts were produced by the parasite itself.

The route of infection needs further study, as well as the annual cycle, the host specifity and the possible presence of an actinosporean stage in the life cycle of the parasite. At present it is not possible to give an exact description of the pathogenesis. This would require better knowledge of the route of infection and the life cycle of the parasite.

The presence of intestinal stages could indicate an alimentary or percutaneous infection, possibly during the tadpole stage of the host. Renal myxosporidiosis in tadpoles has been reported by Desser et al. (1986) from Rana catesbeiana infected with Sphaerospora ohlmacheri Whinery, 1983. However, the juvenile specimens of Hoferellus concolor showed no signs of a myxosporidian infection.

The oral ingestion of mature spores or infected oligochaetes (if an actinosporean stage exists in the life cycle) is unlikely in adults, but a percutaneous infection with an actinosporean stage could be possible during a stay in the water.

This is the first record of Hoferellus species in an amphibian host. The morphological characteristics of the parasite are similar to those described in fish. However, in $H$. anurae the bristle-like appendages are shorter and the spore has a more prominent sutural line (except in H. schulmani). Transmission of myxosporidians from fish to amphibians is not known to occur. Other Hoferellus species in fish seem to be host specific. The transmission of $H$. carassii by the actinosporidian stages to common carp was not successful under laboratory conditions (Trouillier et al. 1996). In consequence, those authors considered $H$. cyprini to be a specific parasite of common carp and $H$. carassii of crucian carp.

No distinct morphological differences were found in the Hoferellus from Afrixalus and Hyperolius; thus, the parasite is described here as a single species. Further investigations are needed regarding the host specificity of this myxosporidian parasite in amphibians.
Hoferellus species have not been described in African fish (Kpachta et al. 1996, Fomena \& Bouix 1996, 1997), making this the first record of this myxosporean genus in African vertebrates.

Acknowledgements.I wish to thank Dr. E. Kuchling (Bernau) for the histological sections, Prof. Dr. J. Lom (Ceské Budejovice) for helping to identify the parasite and for comments on the manuscript, Prof. P. Zwart (Bunnik) for helpful discussion, Dr. I. F. Keymer (Norfolk) for kindly correcting the English, A. Schulze (Berlin) for line drawings and my wife, Caren, for her general support.

\section{LITERATURE CITED}

Achmerov AKh (1960) Myxosporidia of fishes from the Amur river basin (in Russian). Rybn Khoz Vnutr Vod LatSSR 5: 240-307

Ahmed ATA (1973) Morphology and life history of Mitraspora cyprini Fujita parasitic in the kidney of goldfish. Jpn J Med Sci Biol 26:87-101

Ahmed ATA (1974) Kidney enlargement disease of goldfish in Japan. Jpn J Zool 17:37-57

Barddsley JE, Harmsen R (1973) The trypanosoma of anura. Adv Parasitol 11:1-73

Desser SS, Lom J, Dyková I (1986) Developmental stages of Sphaerospora ohlmacheri (Whinery, 1893) n.comb. (Myxozoa: Myxosporea) in the renal tubules of bullfrog tadpoles, Rana catesbeiana, from Lake of two rivers, Algonquin Park, Ontario. Can J Zool 64:2213-2217

Doflein F (1898) Studien zur Naturgeschichte der Protozoen. III. Über Myxosporidien. Zool Jahrb Abt Anat Ontog Tiere $2: 281-350$

Duncan AE (2000) Renal myxosporidia in Asian horned frogs, Megophrys nasuta. ARAV Seventh Annual Conference (Proceedings), Reno, Nevada. Association of Reptilian and Amphibian Veterinarians, Chester Heights, PA, p 23-26

Fomena A, Bouix G (1986) Contribution a l'étude des Myxosporidies des poissons d'eau douce de Cameroun. Acta Trop 43:319-333

Fomena A, Bouix G (1997) Myxosporea (Protozoa: Myxozoa) of freshwater fishes in Africa: keys to genera and species. Syst Parasitol 37:161-178

Fujita T (1912) Notes of new sporozoan parasites of fishes. Zool Anz 39:259-262

Golikova MN (1960) Eco-parasitologic examinations of the biocoenosis of some lakes in the Kaliningrad district (in Russian). Vesn. Leningrad Gos. Univ. 9. Ser. Biol. 2: $110-121$

Joseph H (1905) Chloromyxum protei n. sp. Zool Anz 29: $450-451$

Körting W, Hermanns W (1984) Myxosporidien-Infektionen in der Niere des Karpfens (Cyprinus caprio L.) aus niedersächsischen Teichwirtschaften. Berl Münch Tierärztl Wochenschr 97:255-259

Körting W, Hermanns W (1985) Mitraspora cyprini Fujita, 1912 (Protozoa: Myxosporea Bütschli, 1881) in der Niere der Karpfen in niedersächsischen Teichwirtschaften. Berl Münch Tierärztl Wochenschr 98:63-64

Kpachta TK, Diebakate C, Toguebaye BS (1996) Myxosporidies (Myxozoa, Myxosporea) des genres Sphaeromyxa Thélohan, 1892, Myxidium Bütschli, 1882, Zschokkella Auerbach, 1910, Bipteria Kovaljova, Zubtchenko \& Krasin, 1983 et Leptotheca Thélohan, 1895 parasites des poissons 
des côtes sénégalaises (Afrique de l'Ouest). J Afr Zool 110(4):309-317

Kudo R (1920) Studies on Myxosporidia. Ill Biol Monogr 3: $1-265$

Levine ND, Nye RR (1977) A survey of blood and other tissue parasites of leopard frogs Rana pipiens in the United States. J Wildl Dis 13:17-23

Lom J (1990) Phylum Myxozoa. In: Margulis L, Corliss JO, Melkonian M, Chapman DJ (eds) Handbook of Protista. Jones and Bartlett Publishers, Boston, MA, p 36-52

Lom J, Dyková I (1981) Pathogenicity of some protozoan parasites of cyprinid fishes. Fish, Pathogens and enviroment in European polyculture. In: Oláh J, Molnár K, Jeney Z (eds) Proc Intern Seminar, Szarvas, p 184-197

Lom J, Dyková I (1992) Protozoan parasites of fishes. Elsevier Science Publishers BV, Amsterdam

Lom J, Noble ER (1984) Revised classification of the class Myxosporea Bütschli, 1881. Folia Parasitol (Prague) 31: 193-205

Molnár K, Csaba G, Kovacs-Gayer E (1986) Study of the pos-

Editorial responsibility: Peernel Zwart,

Utrecht, Netherlands tulated identity of Hoferellus cyprini (Doflein, 1898) and Mitraspora cyprini Fujita, 1912. Acta Vet Hung 34 (3/4): 175-181

Mutschmann F (1999) A new myxozoan, Chloromyxum careni sp. n. (Myxosporea: Chloromyxidae) from the kidney of Megophrys nasuta Schlegel, 1858 (Anura: Pelobatidae) from Indonesia. Acta Protozool 38:83-86

Ohlmacher AP (1893) Myxosporidia in the common toad, with preliminary observations on two chromophile substances in their spores. J Am Med Assoc 20:561-567

Plehn M (1924) Praktikum der Fischkrankheiten. Schweizerbartsche Verlagsbuchhandlung, München

Schiøtz A (1999) Treefrogs of Africa. Chimaira, Frankfurt am Main

Thélohan P (1895) Recherches sur les Myxosporidies. Bull Sci Fr Belg 26:100-394

Trouillier A, El-Matbouli M, Hoffmann RW (1996) A new look at the life-cycle of Hoferellus carassi in the goldfish (Carassius auratus auratus) and ist relation to 'kidney enlargement disease' (KED). Folia Parasitol 43:173-187

Submitted: January 2, 2003; Accepted: March 3, 2004

Proofs received from author(s): August 12, 2004 